\title{
A Case Study of Copper-Arsenic Ewer from the Egyptian Museum in Cairo, Egypt
}

\section{Dr. Abeer Gharib Abd Allh Dr. Manal Ahmed Maher ${ }^{\bullet \bullet}$}

\section{Abstract:}

This paper presents an analytical study and treatment of an Arsenical Copper ewer from old kingdom stored in the Egyptian Museum in Cairo. Examination and analysis were carried out by using optical microscopy (OM), metallographic microscopy and scanning electron microscopy (SEM), with energy-dispersive spectroscopy (EDX) and X-ray diffraction (XRD).

Results indicated that ewer was made of copper-arsenic alloy; it had intended black layer which referred to the fertile soil. The ewer was made by cold-working and the spout was joined mechanically; it has three layers of alteration products with various compositions and morphology covering the substrate of the alloy. XRD results indicated that the ewer was subjected to many corrosive ions such as chloride and sulfur. This study provides useful information that helped in preserving this unique ewer.

\section{Keywords:}

Copper-Arsenic Alloys, Mechanically Joined, OM, SEM-EDX, Metallographic microscopy, XRD, Treatment.

\footnotetext{
- Assistant Professor Doctor, Conservation department, Faculty of Fine Arts, Minia University, 61519, Minia, Egypt*Corresponding author: abeer.ibrahim@,mu.edu.eg

•• Doctor, Physicist in Egypt Nano Technology Center (EGNC), Cairo University, 12588, Sheikh Zayed
} 


\section{Introduction}

The study of ancient metals has produced an important aspect of archaeological interpretation; it was unexpected to early archaeological scientists to find that tin bronze was not the first prehistoric alloy believed to be, but that many early objects were rather made of arsenical copper ${ }^{(1)}$.

Archaeologists consider the Chalcolithic period as the name that immediately preceded the Bronze Age in which metals were first being mastered, and they date this period between approximately 5000 and 3000 B.C. Ancient man first used native or naturally occurring and relatively pure metals such as copper ${ }^{(2)}$.

Copper objects have a small percentage of impurities; the major impurities are arsenic, antimony, lead, iron, zinc, tin, etc. The presence of these impurities with their different percentage depends upon the ore which is derived from and the metallurgical processes which are performed to produce them ${ }^{(3)}$. Copper alloying is considered as a mixture of copper with other elements to improve some of its properties. Alloy might have happened by the knowledge of the ancient smiths, and by mixing certain minerals with copper ore, the quality of the product was improved $^{(4)}$.

Both arsenic and tin present a deoxidizing agent into copper, which greatly influences the mechanical properties and the ability to cast the copper. It is recognized that the first step in alloying

\footnotetext{
${ }^{(1)}$ Loïc C. Boscher, " Reconstructing the Arsenical Copper Production Process in Early Bronze Age Southwest Asia", PhD, University College London, UCL Qatar, 2016, P.26

${ }^{(2)}$ Reardon, A.C., "Metallurgy for the Non-Metallurgist", ASM International, 2011, P.73

${ }^{(3)}$ Lutfia. H. Khalil, "The Composition and Technology of Copper Artifacts from Jericho and Some Related Sites", PhD, Department of Archaeological Conservation and Materials Science, Faculty of Arts of the University of London, 1980, P.7.

${ }^{(4)}$ Von der Fakultät für Werkstoffwissenschaft und Werkstofftechnologie', "Material properties of copper alloys containing arsenic, antimony, and bismuth The material of Early Bronze Age ingot torques”, PhD, Technischen Universität Bergakademie Freiberg, 2003, p. 4.
} 
started with arsenic, and that by the third millennium B. C. the copper-arsenic alloy was dominant ${ }^{(5)}$.

Arsenic is found as traces in most ancient Egyptian objects made of copper from the Naqada culture until the second Intermediate period; since the Middle kingdom ${ }^{(6)}$. Arsenic did not exist in native copper in any quantities, and its alloy with copper appeared in the $5^{\text {th }}$ and $4^{\text {th }}$ millennia $\mathrm{BC}$ and tends to contain over $1 \mathrm{wt}$. \% of Arsenic is the easily volatilized and highly toxic nature which has been explained as the main reason behind arsenical copper's demise and ultimate replacement by tin bronzes ${ }^{(7)}{ }^{(8)}$; arsenic has low boiling point of $613^{\circ} \mathrm{C}$, which means that it could easily escape during melting ${ }^{(9)}$. It is also strongly reactive to oxygen, and readily forms the highly toxic compound arsenic trioxide $\left(\mathrm{As}_{2} \mathrm{O}_{3}\right)$ under oxidizing conditions. This compound is even more volatile, and with a boiling point of just $465^{\circ} \mathrm{C}$ it will easily sublimate from a smelt ${ }^{(10)}$. It should be mentioned that release of this arsenic trioxide can be easily observed as a white vapor with garlic odor, although addition of arsenic in copper improved mechanical properties of the resulting alloy specially in cold hammering operation ${ }^{(11)}$.

It is believed that the earliest occurrence of these alloys is the result of the melting of ores containing both copper and arsenic. The simplest and most likely origin for the earliest alloys is the reduction of copper arsenates; these arsenates are identical to

\footnotetext{
${ }^{(5)}$ Lutfia. H. Khalil, Op. Cit., P.7.

${ }^{(6)}$ Martin Odler, " Old Kingdom Copper Tools and Model Tools", ARCHAEOPRESS Publishing Ltd, Oxford, 2016, P.238

(7) Srinivasan, S., and Ranganathan, S., "Nonferrous Materials Heritage of Mankind", Trans. Indian Ins. Met., Vol.59, No.6, December, 2006, p. 840

${ }^{(8)}$ Meliksetian K., Schwab R., Kraus S., Pernicka E.and Brauns M., "Chemical, lead isotope and metallographic analysis of extraordinary arsenic-rich alloys used for jewellery in Bronze Age Armenia", Metalla (Bochum) Sonderheft, 4, 2011, p. 211.

${ }^{(9)}$ Subramanian, P.R., and Laughlin, D.E., " The As-Cu (Arsenic-Copper) system", Bulletin of alloy phase Diagram, Vol.9, No. 5, 1988, p. 606

${ }^{(10)}$ Loïc C. Boscher, Op. Cit., pp. 45-48.

${ }^{(11)}$ Martin Odler, Op. Cit., p. 238.
} 
those of purer copper oxide and hydroxides such as malachite and azurite and would not have needed any additional skills or knowledge to extract. The facility of extracting arsenical copper from these types of ores has been established through a series of smelting experiments which shows that a lightly reducing atmosphere led to the formation of fully molten copper metal ${ }^{(12)}$. Egyptian expeditions record the most copper ores from Sinai and the Eastern Desert of Egypt ${ }^{(13)(14)(15)}$

This paper presents a study of the chemical composition of the selected ewer, and the elements and their distribution on the surface and on the cross section of the ewer to explain the nature of the alloy. By using optical microscope OM; metallographic microscope; SEM-EDX, and having analyzed the surface structures and the interference area with the metallic core of the basic alloy, intending to elucidate the technology used during the manufacture of the ewer in old kingdom period in Egypt.

\section{Materials and Methods}

\section{Description and condition}

The selected black ewer (Fig. 1, 2) had the temporary No. Cg 3476 and is stored at the Egyptian Museum in Cairo and dated back to the Old Kingdom (2613-2181 B.C.) ${ }^{(16)(17)}$; it is $10.5 \mathrm{~cm}$ high and 7.9 diameter. This type of ewer was public in the Early Dynastic and Old Kingdom periods; such ewers made of arsenical copper or bronze alloy. The ewer with a wide open

\footnotetext{
${ }^{(12)}$ Loïc C. Boscher, Op. Cit., p.53.

${ }^{(13)}$ George Brinton Philips, "The Composition of some Ancient Bronze in the Dawn of the Art of Metallurgy", American Anthropologist, New Series, Vol.24, 1922, p.130

${ }^{(14)}$ Abd El-Rahman, Y., Surour, A.A., El Manawi, A.H.W., Rifai, M, Abd El Motelib, A., and El Dougdoug, A.M., "Ancient mining and smelting activities in the Wadi Abu Gerida area, central eastern desert, Egypt, preliminary results", Archaeometry, 55, 2013, p.1075.

(15) - Stephen Michael Vinson, Boats of Egypt before the Old Kingdom, M.A, College of

Texas A\&M University, 1987, p. 30.

${ }^{(16)}$ http://www.reshafim.org.il/ad/egypt/trades/metals.htm 5-1-2018.

(17) https://www.ancient.eu/Old Kingdom of Egypt/21-3-2018.
} 
mouth and short spout is dated to the middle of the Second Dynasty. Other early ewers have similar open mouths, but also longer and more slender spouts. In the Early Dynastic and Old Kingdom periods, the ewer developed proportionately taller and its bottom and opening became relatively smaller, and the spouts turned noticeably longer (Fig.3) ${ }^{(18)}$. The ewers and basins are used in everyday life for washing hands. Then, they were supposed to function in ritual use during the Old Kingdom ${ }^{(19)}$.The ewer was covered with an extremely disfiguring black crust and some parts from the body were missing. The inside surface of ewer was covered with a colored incrustation of a variety of corrosion compounds.
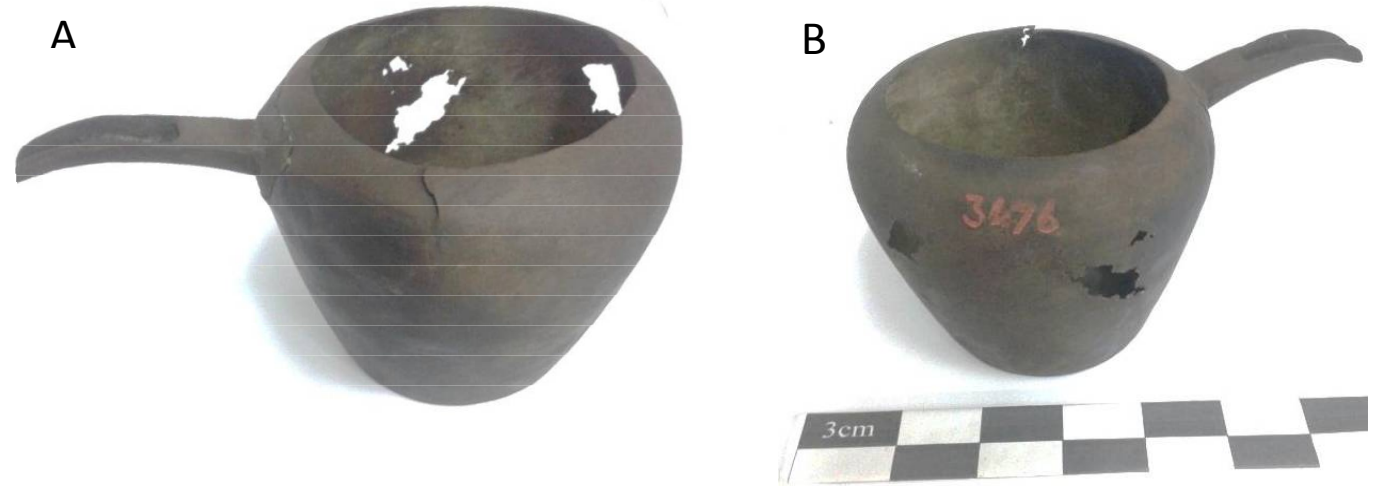

Fig. 1 the copper-arsenic ewer A) from the right side and B) from the left side showing missing parts and corrosion layer

\footnotetext{
${ }^{(18)}$ https://www.google.com.eg/search?q=old+kingdom+longer+Ewer+figure\&tbm 21-32018

${ }^{(19)}$ Schorsch, D., "Copper Ewers of Early Dynastic and Old Kingdom Egypt in Antiquity", Philipp Von Zabern, Mainz am Rhein, 1992, pp. 145-146.
} 


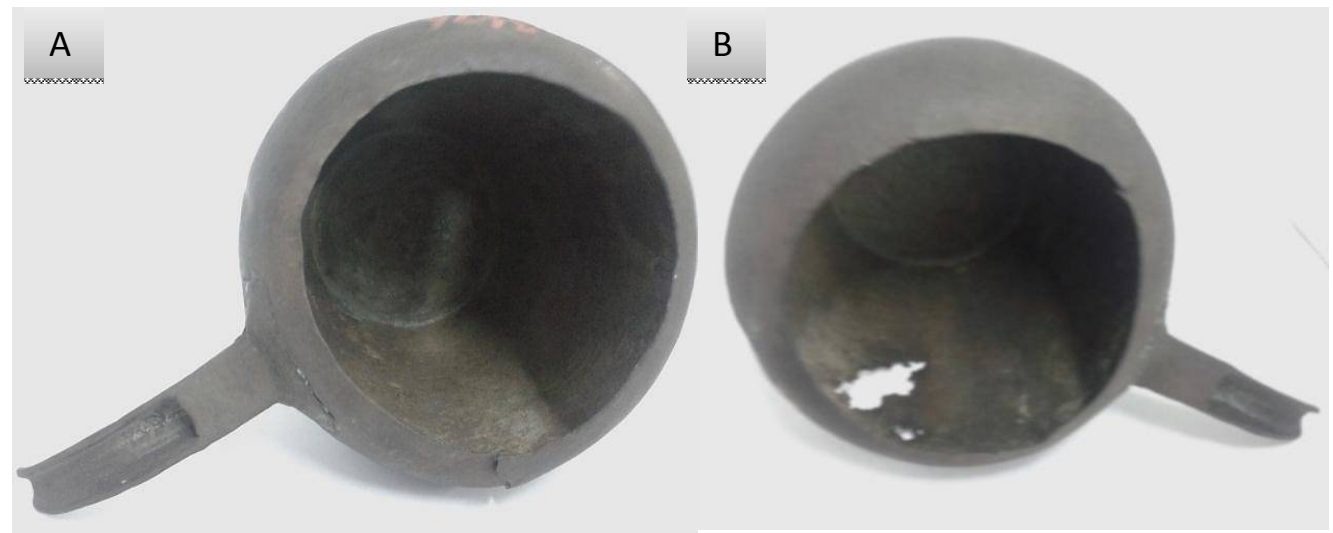

Fig.2 (A, B) shows corrosion layer inside the copper-arsenic ewer
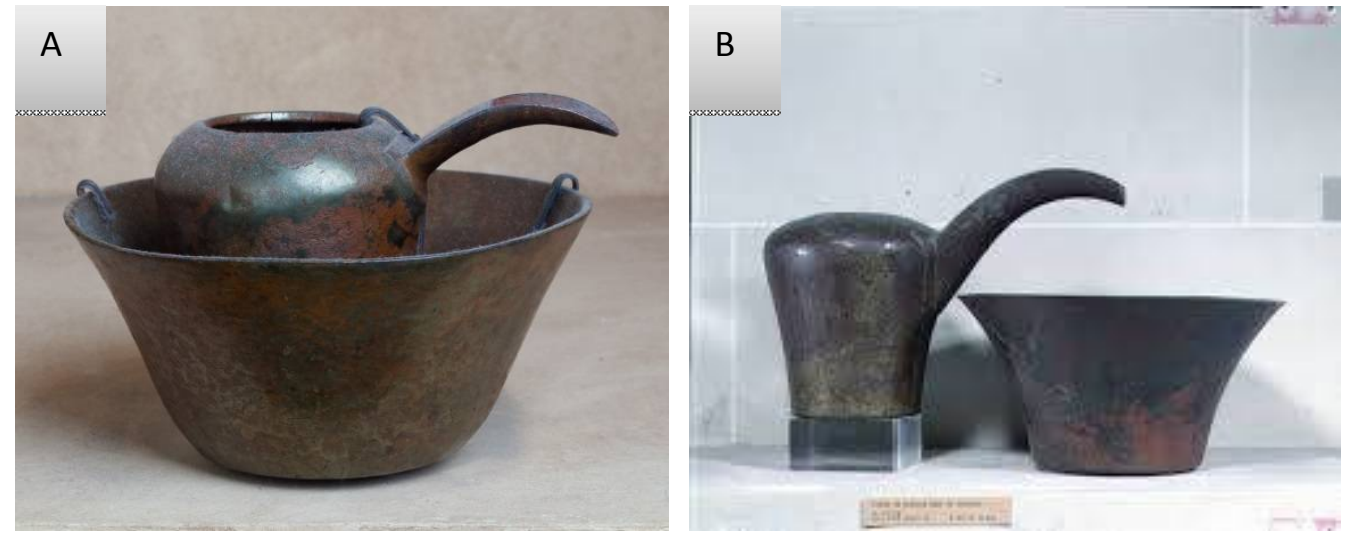

Fig. 3 shows different type of Ewers with basin A) Ewer with a wide open mouth and short spout from the middle of the Second Dynasty B) Ewer developed proportionately taller and its bottom and opening relatively smaller

\section{Examination and Analysis}

\section{Optical Microscopy}

The microscopic examinations were carried out using a Smart-Eye USB Digital Microscope at various magnification degrees, up to maximum 200X, for the investigation of the corrosion products characteristics and the morphology of the corrosion layer and the core of the ewer. 


\section{Metallographic microscope}

The cross-section of the alloy was investigated by metallographic microscope. Macroscopic observations allowed us to identify the corrosion deposits and layers that completely cover the surface of the ewer, their color, nature, and shape. The sample designated for optical microscopy observation was fixed in the Epoxide 20-8130 with hardener 20-8132. ${ }^{(20)}$ The fixed cross section was grounded with $\mathrm{Si} \mathrm{C}$ abrasive paper and then polished and detergent at a rotary polishing wheel. Metallic cross-section was etched by $3 \%$ solution of ammonia in hydrogen peroxide which gives a good result in approximately $0.5 \%$

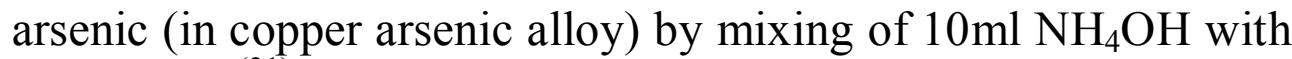
$2 \mathrm{ml} \mathrm{H}_{2} \mathrm{O}_{2}$. ${ }^{(21)}$ The observation was performed using the optical metallographic microscope Olympus BX41M provided with digital video camera and connected to PC computer.

\section{SEM - EDX}

Scanning electron microscopy (SEM) coupled with energy dispersive spectrometry (EDX), was used to examine the surface and the metallic core and to detect the distribution of the chemical elements on the corrosion layer and in the cross section. SEM micrographs and EDX spectra of the selected ewer were obtained by using SEM-EDX apparatus from El Tebeen Institute in Cairo model FEL INSPECT S50, EDX QUANTAX Burker. The examination conditions were low vacuum mode at 0.8 tors. Backscatter electron images of the samples were scraped at acceleration voltage $25.0 \mathrm{kv}$ with back scattered detector (BSE) at $5 \mathrm{~mm}$ working distance and spot size 6 .

\footnotetext{
${ }^{(20)}$ Scott, D.A., "Metallography and microstructure of ancient and historic metals", The Getty Conservation Institute, The J. Paul Getty trust, 1991.

${ }^{(21)}$ Dmitri, K.," The Metallographic Examination of Archaeological Artifacts", Summer Institute in Materials Science And Material Culture, 2003.
} 


\section{X-ray Diffraction Analysis (XRD)}

XRD analysis was used to identify the corrosion products covering the surface, and to recognize the corrosive conditions that led to the corrosion of the ewer. Sample was taken mechanically by scraping the corroded surface gently with a very fine tungsten needle, ground to a fine powder in an agate mortar then mounted in using a PAN analytical X'pert PRO Diffractometer. In fixed analysis condition; secondary monochramtor with $\mathrm{Cu}-\mathrm{K} \alpha 1$ target of $\lambda 0.1542 \mathrm{~nm}$, operated at generator power $45 \mathrm{KV}$ and $40 \mathrm{~mA}$. The scanning step rate and range were $0.02^{\circ}, 0.05^{\circ} / \mathrm{s}$ and $70^{\circ}$, respectively. The $2 \theta$ values and relative intensities (I / Io) were determined from the chart.

\section{Results}

Visual examination of the studied ewer revealed that it generally has a uniform and compact black patina in the outer surface, with little difference in the appearance and some green patina in the inner surface.

The characterization of the surfaces by Optical microscope, Scanning Electron Microscopy (SEM) and metallographic microscope examinations was primarily carried out. The effects of the processes of chemical alteration on the surface of the alloy are obvious in the alteration crust formed on the mineralized surface. The surface pattern seems heterogeneous at first sight optical and SEM examinations. The corrosive features such as rough; powder or compact corrosive surface, thin corrosive layer and cracks or fissures were noticed. Micro photos of the surface corrosion layer revealed different colors of the deposited layer; green to dark green, and white (figs. 4, 5).SEM- EDX analysis (fig.6) Table 1 identified the arsenic copper alloy as copper the base mineral with percentage $78.6 \%$ and arsenic $0.87 \%$ in addition of some corrosion anions such as $\mathrm{Cl}(21.9 \%)$, $\mathrm{S}$ $(1.84 \%)$ and $\mathrm{O}(25.25 \%)$. 

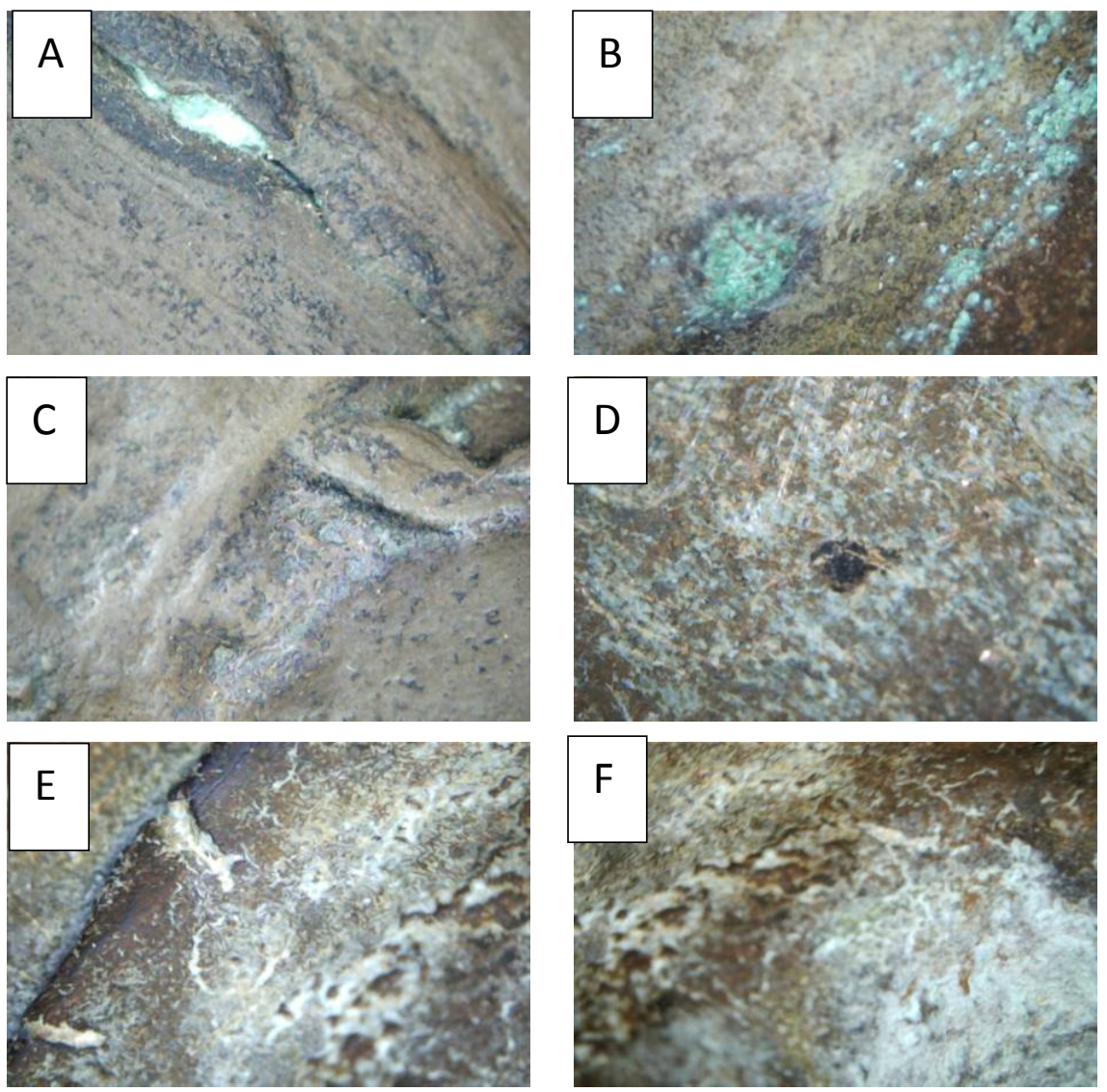

Fig.4 Optical observation (200X) of the copper-arsenic ewer shows A, B) light green corrosion inside fissure and crevice, C, D) heterogeneous corrosion and appearance of cavitation erosion E, F) thin white corrosive layer and cracks 


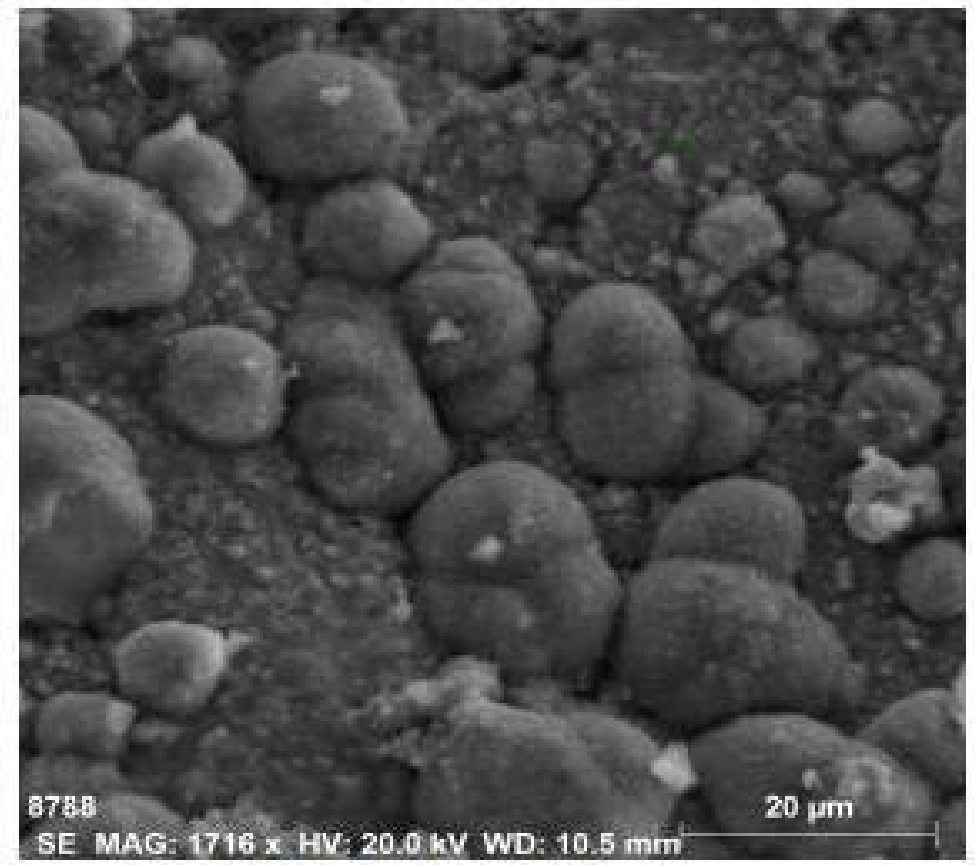

Fig.5 photo of the surface corrosion layer revealed the corrosive features rough and powder with different colors of the deposited layer 

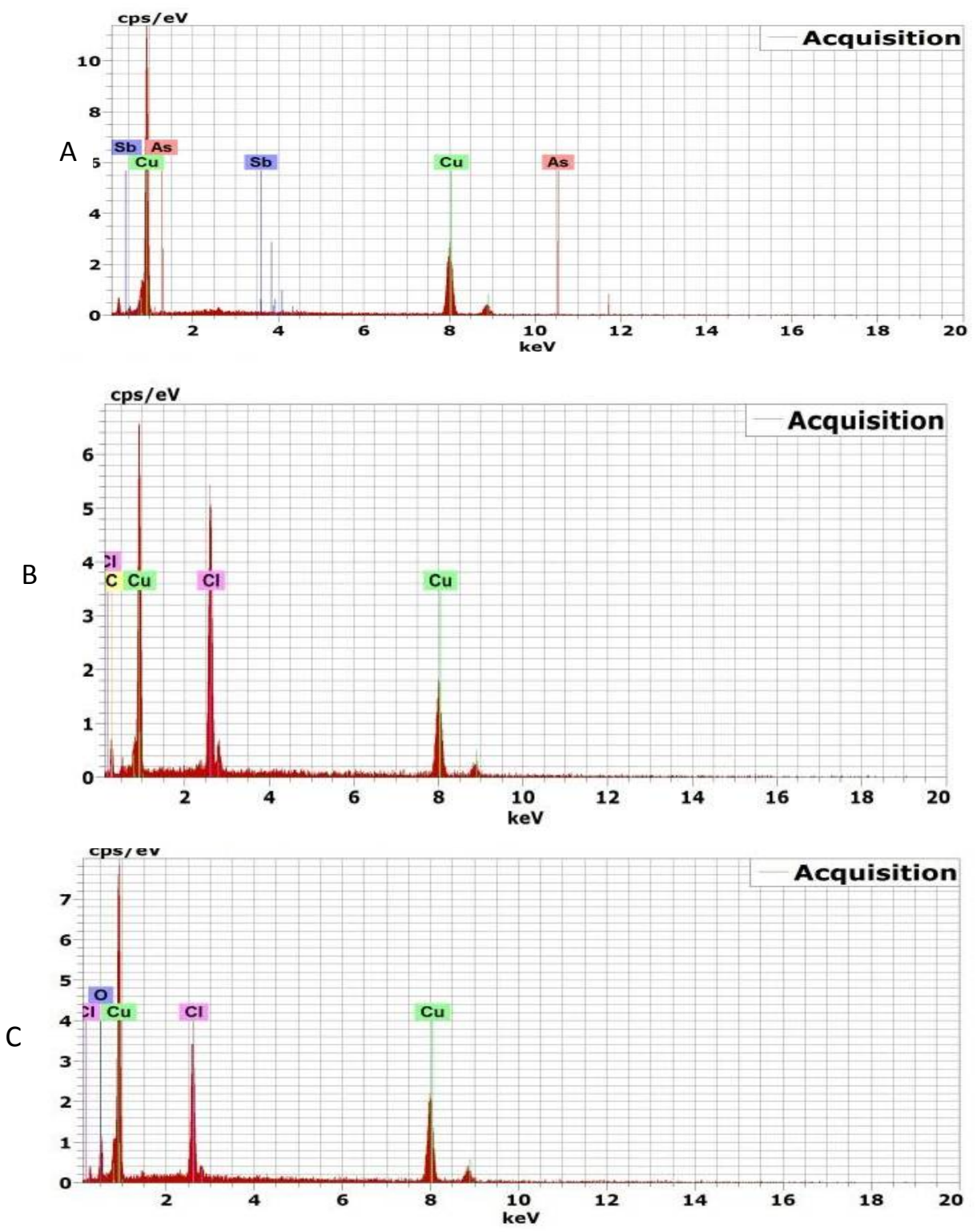

Fig.6 showed SEM-EDX A) identified the arsenic copper alloy as copper the base mineral with percentage $78.6 \%$ and arsenic $0.87 \% \mathrm{~B}$ ) showed $\mathrm{Cl}$ anions $(21.9 \%)$, and $\mathrm{C})$ some corrosion anions as $\mathrm{S}(1.84 \%)$ and $\mathrm{O}$ 
Table 1: chemical composition determined by SEM- EDX analysis A) identified the arsenic copper alloy as copper the base mineral with percentage $78.6 \%$ and arsenic $0.87 \% \mathrm{~B}$ ) showed $\mathrm{Cl}$ anions $(21.9 \%)$, and $\mathrm{C}$ ) some corrosion anions as $\mathrm{S}(1.84 \%)$ and $\mathrm{O}(25.25 \%)$.

A

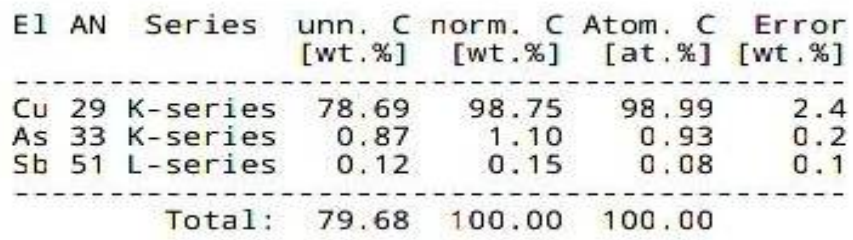

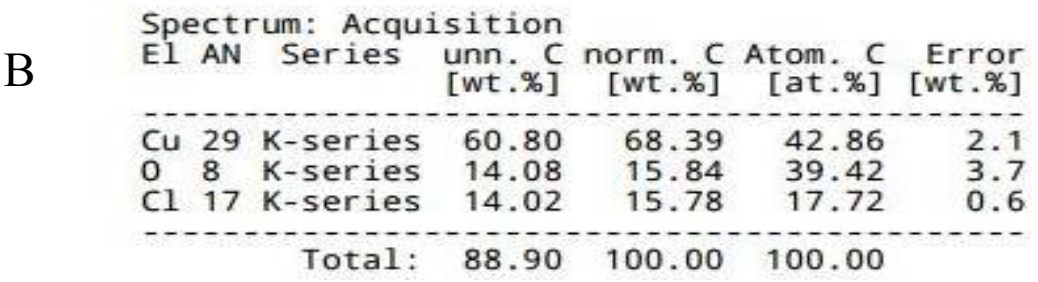

$\begin{array}{llllrrr}\text { El AN } & \text { Series unn. C norm. C } & \text { Atom. C } & \text { Error } \\ \text { [wt.\%] } & \text { [wt.\%] } & \text { [at.\%] } \\ \text { [wt.\%] }\end{array}$

The optical micrograph image (fig.7) of the metallic crosssection after etching determined the patina has a sandwich structure, in which the layers of the primary patina are overlapped or partially interjected with the ones of the secondary patina. Strata-graphical morphology characterized the most archaeological patinas of ancient metallic objects ${ }^{(22)}$.

\footnotetext{
${ }^{(22)}$ Mohamed Ghoniem, "The Characterization of a Corroded Egyptian Bronze Statue and A Study of the Degradation Phenomena", International Journal of Conservation Science, Volume 2, Issue 2, April-June, 2011, p. 97.
} 


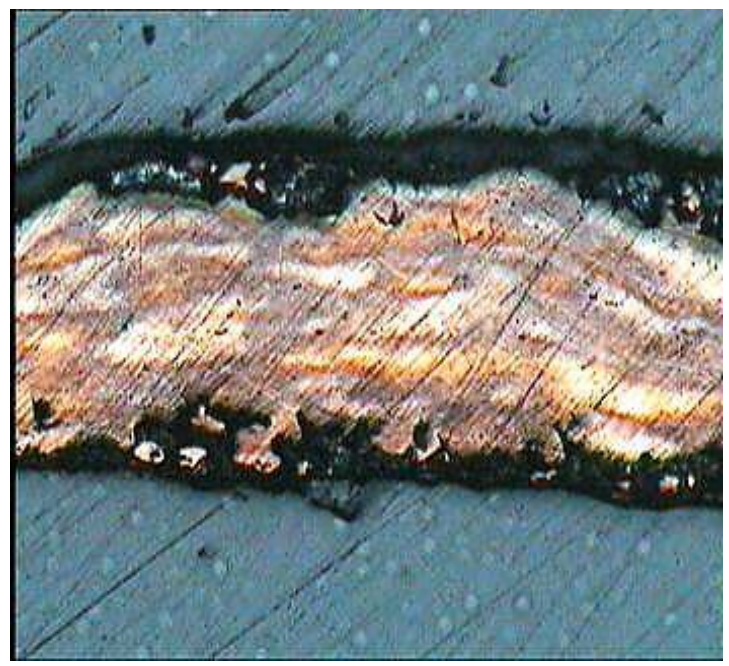

Fig.7 shows metallographic cross-section that appear corrosion layers in sandwich structure

The observation microphotographs (Fig. 8) show the colors, the thickness, and the layer morphology of the patina. The secondary electron images of a cross section of the corrosion product sample appeared a multiphase structure of different minerals, which were analyzed by SEM-EDS. The matrix of the sample is formed by copper with the presence of arsenic and chlorine.

The corrosion products of the copper arsenic alloy were identified by XRD (fig.9) and table 2 showed a mixture of minerals as copper $(\mathrm{Cu})$, copper oxide Tenorite $(\mathrm{CuO})$ accompanied by copper sulfide Lautite $(\mathrm{CuAsS})$, Whitneyite $\left(\mathrm{Cu}_{9} \mathrm{As}\right)$ and copper chloride mineral as $\left(\mathrm{Cu}_{2} \mathrm{Cl}(\mathrm{OH})_{3}\right.$ Paratacamite. 

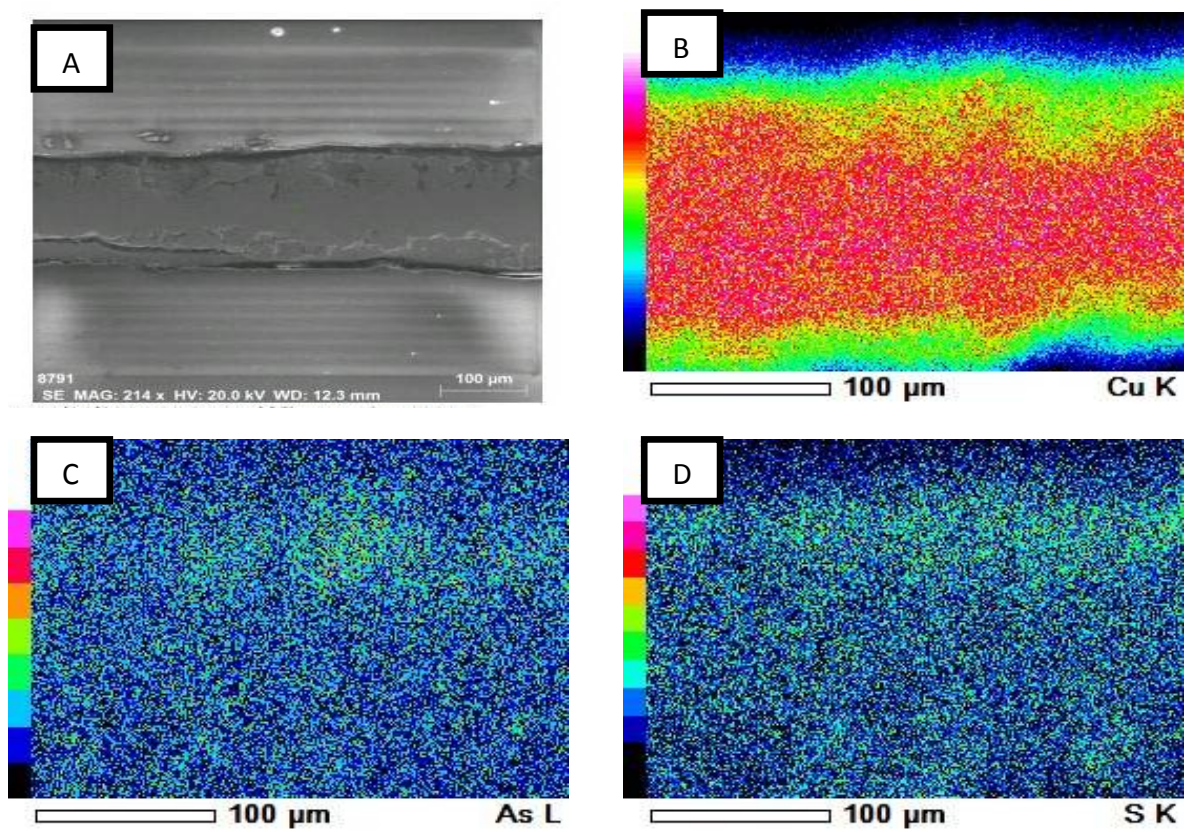

Fig.8 Identification of inclusions by SEM cross-section A, B) showed copper in the middle as a core

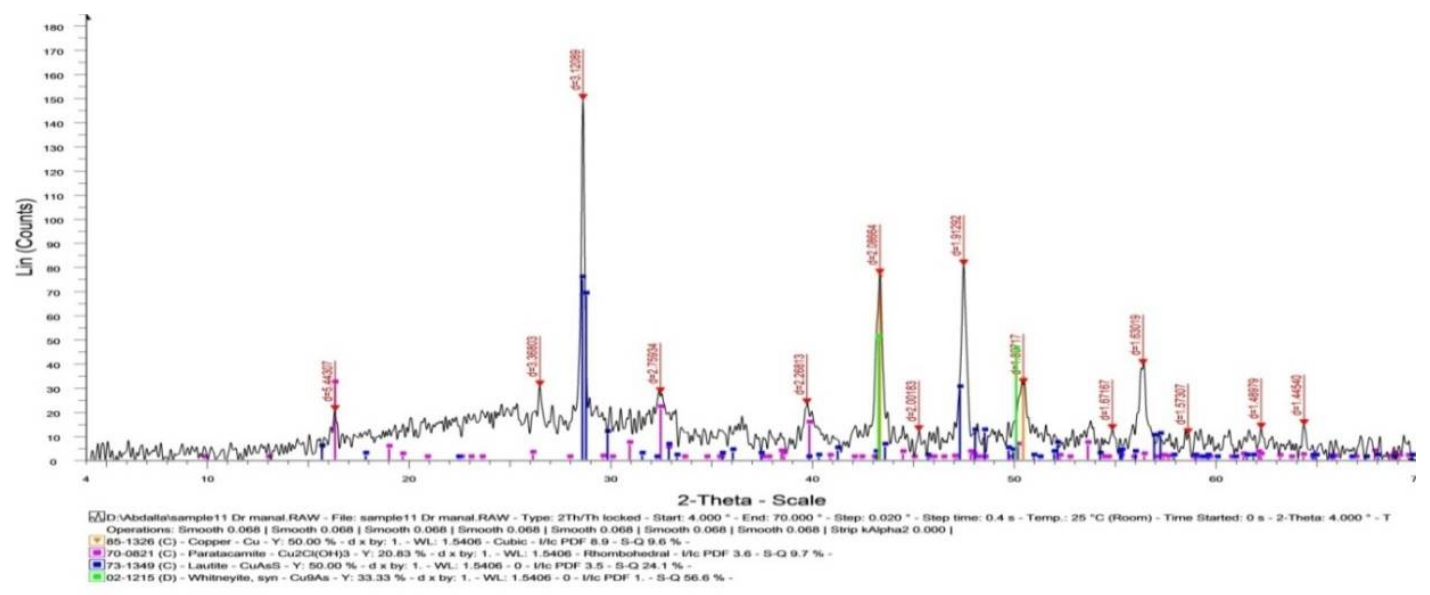

Fig.9 showed XRD pattern of the ewer with copper as the base mineral, paratacamite as the main corrosion product and copper sulfide presents as 
$(\mathrm{CuAsS})$ lautite and $\left(\mathrm{Cu}_{9} \mathrm{As}\right)$ whitneyite; in addition of traces of tenorite copper oxide $(\mathrm{CuO})$.

Table2. Mineralogical composition of corrosion products sample obtained by XRD

\begin{tabular}{ccc}
\hline Minerals & Formula & Content \\
\hline Copper & $\mathrm{Cu}$ & Major \\
lautite & $\mathrm{CuAsS}$ & Major \\
\hline Paratacamite & $\mathrm{Cu}_{2}(\mathrm{OH})_{3} \mathrm{Cl}$ & Minor \\
whitneyite & $\mathrm{Cu}_{9} \mathrm{As}$ & Traces \\
\hline Tenorite & $\mathrm{CuO}$ & Traces \\
\hline
\end{tabular}

\section{Treatment procedures}

The copper-arsenic ewer has high archaeological value, so treatment of this object had to be approached with wellestablished methods; to be stable during and after treatment. The mechanical cleaning process for interior metallic surfaces carried out by different brushes which were selected to remove the bulk of the corrosion deposits, the ewer sometimes required to be wetted very regularly with methylated spirits to help through the mechanical cleaning process. The chloride components of copper arsenic alloy removed with a 5\% Rochelle salt solution (150 gm. Sodium Potassium Tartrate with $50 \mathrm{gm}$. Sodium hydroxide) followed by a $5 \%$ Citric acid solution, the hydroxyl ions of the alkaline solution react chemically with the insoluble chlorides to form cuprous oxide and soluble sodium chlorides ${ }^{(23)}(24)$; then the ewer was carefully washed by distilled water and dried with methyl alcohol; after complete dryness we consolidated the inner surface with glass fiber sheets with $15 \%$ polaroid B.72 in acetone as a supported layer, then we used Nano- copper oxide

\footnotetext{
${ }^{(23)}$ Hamilton, D.L., "Methods of conserving archaeological material from underwater sites", Texas University, Texas, 1999, P.83

${ }^{(24)}$ Selwyn,L., and Binnie, N., "Metal corrosion rates in aqueous treatments for water logged wood- metal composites", Journal of studies in conservation, 38, 1993, pp. 197-180..
} 
filler with $50 \%$ polaroid B.72 in outer surface; this reversible material is suitable for completing missing parts of ewer according to its composition, and finally the ewer was isolated with 4\% polaroid B.72 in acetone (Fig. 10).

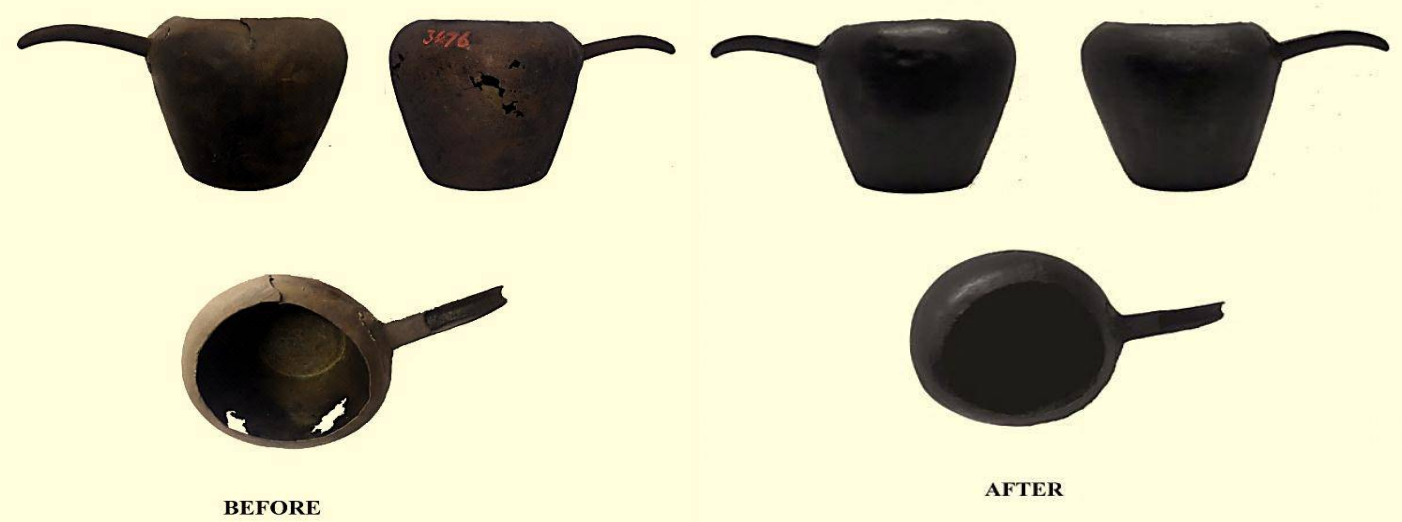

Fig.10 shows the copper-arsenic ewer before and after treatment processes

\section{Discussion}

Visual examination revealed that the ewer has compact black patina, reflecting the color of the fertile soil of (the Black Land), one of Egypt's names; indicating fertility and regeneration; and the color of the underworld. ${ }^{(25)(26)}$.

The mechanical characteristics of alloy related to the structure; the determination of physical, mechanical properties and chemical composition of the alloy helped in identifying the technology applied to the ewer ${ }^{(27)}$

\footnotetext{
${ }^{(25)}$ Maickel Van Bellegem, Philip Fletcher, Paul Craddock,Susan La Niece and Richard Blurton, "The black bronzes of Burma, The black bronzes of Burma", The British Museum, Vol.1, 2007, p. 55.

${ }^{(26)}$ Mohamed, W., and Darweesh, S., “Ancient Egyptian Black-Patinated Copper Alloys", Archaeometry, 54, 2012, p. 175.

${ }^{(27)}$ Lutfia. H. Khalil, Op. Cit., p. 36.
} 
The ewer was made separately of its spout; by hammering and mechanically joining spouts. The spout seems cast and is $U$ shaped in cross- section; it flanges for attachment to the ewer (Fig.11) ${ }^{(28)}$. The inner flanges are usually larger than the corresponding outer one; (Fig.12); therefore it can be observed as thinning and cracking around the edges (Fig.4A) which is characteristic of this hammering process and the stresses it generates in metal.

The ewer was made by different ways leading to deformation in the grains; the initial grain structure of a homogeneous alloy can be characteristic as hexagonal grains. When these grains are deformed by hammering they flattened (their shape is distorted by slip, dislocation movement, and the generation of dislocations as a result of working) until they are too brittle to work any further. At this point, the grains are said to be fully workhardened ${ }^{(29)}$. The dislocations act together and with grain boundaries and inclusions. At a certain degree of distortion the motion of the dislocations is impeded. If the material is further deformed its structure will be damaged by cracks until the material fails ${ }^{(30)}$.

Optical image obtained from surface revealed the presence of gray dark tenorite, in addition to light green corrosion products and white compounds which present remaining soil particles ${ }^{(31)}$.

\footnotetext{
${ }^{(28)}$ Schorsch, D., Op. Cit.,, p 154.

(29) Scott, D.A., Op. Cit., p. 6.

${ }^{\left({ }^{30}\right)}$ Frame, L.D., Freestone, I.C., Shu Yan Zhang, and Nicholas, M., "The effects of corrosion and conservation treatments on non-destructive neutron diffraction analysis of archaeological copper alloys: preliminary results", Archaeometry, 55, 2013, pp. 69-70

${ }^{(31)}$ Ivan De Ryck, Emmanuel Pantos and Annemie Adriaens, "Near Eastern ancient bronze objects from Tell Beydar (NE-Syria): into their Corrosion", Euro-physics News, Vol.38, No.5, 2007, p. 31.
} 
A

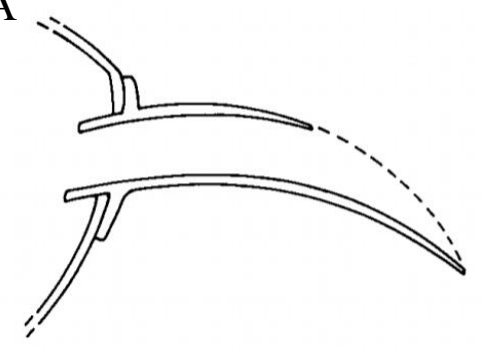

B

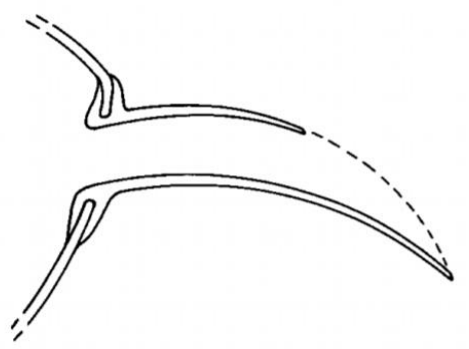

Fig.11 A) diagram of cast spout before mechanical attachment, B) diagram of cast spout after mechanical attachment, after Schorsch, D., Op. Cit., p 154.
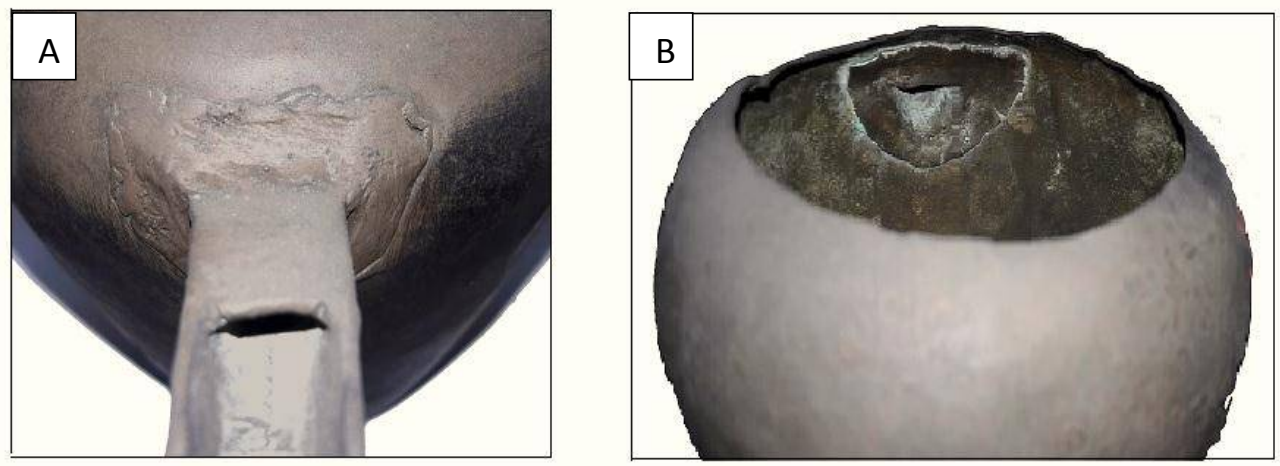

Fig.12 shows mechanical joined of spout with the ewer a) from the outer surface and $b$ ) from the inner

Optical micrographs revealed the corrosive features rough and powder with different colors of the deposited layer; the cross-section showed it had a sandwich structure. Metallography investigation confirmed these results through a cross-section of a sample as seen through a reflecting optical microscope.

Scanning electron microscopy (SEM) examination identified inclusions; inclusions are foreign particles appeared distributed throughout the structure of a metal. They can be created during melting and related to ores, fluxes, incompletely dissolved 
metallic alloy or impurities. Identification of inclusions by examination of their color under SEM microscope carried out (Fig.8 c, d) showed light blue inclusions represented arsenic and sulfide ${ }^{(32)}$; while copper appeared as orange surrounded by light green layer of paratacamite (Fig.8b). The SEM cross-section (Fig. 8a) showed copper in the middle as a core metal then layers of paratacamite and in the top layers there were arsenic and sulfide.

XRD and SEM-EDX analysis identified the alloy which consists of copper-arsenic alloy and copper as the base material (copper $78.6 \%$ and arsenic $0.87 \%$ ), paratacamite as the main corrosion product and copper sulfide presents as $(\mathrm{CuAsS})$ lautite; in addition of traces of $\left(\mathrm{Cu}_{9} \mathrm{As}\right)$ whitneyite and tenorite copper oxide.

The copper oxide mineral tenorite of grey-black color is the principal corrosion product of copper; it usually occurs directly connected with the metallic surface ${ }^{(33)}$. Atacamite, and paratacamite, minerals of pale green color are often associated with specific corrosion deterioration of archaeological metals called 'bronze disease'. These unstable compounds are produced by a reaction of mineral nantokite $(\mathrm{CuCl})$ with moisture and oxygen. This reaction takes place after the removal of the object from the soil environment due to chlorides combined with the corrosion layers. This type of corrosion can lead to very serious chemical and mechanical deterioration of archaeological ewer resulting in cracking or fragmentation. Chloride ions necessary for the course of the reaction created mainly from the degradation process of organic materials that occur in the immediate vicinity of the object ${ }^{(34)}$. Copper sulfides presented in the metallic

\footnotetext{
${ }^{(32)}$ Lutfia. H. Khalil, Op. Cit., p. 44.

${ }^{(33)}$ Scott, D. "A Copper and Bronze in Art: Corrosion, Colorants", Conservation. Los Angeles, J. P. Getty Museum, 2002, P.82

${ }^{(34)}$ Selwyn, L., "Metals and Corrosion: A Handbook for the Conservation Professional. Canada", Canadian Conservation Institute, 2004, P. 66
} 
structures could be interpreted as an impurity originating through the object production ${ }^{(35)}$. Corrosion layers enriched with arsenic acts an important role in the evaluation of the elemental composition of alloys and can lead to distorted results. A presence of this layer is rather the result of the corrosion process in the soil, where migration of arsenic ions to the metal surface took place, resulting in the formation of corrosion products with a higher concentration of this element ${ }^{(36)}$.

\section{Conclusion}

The unique copper-arsenic ewer had highly archaeological value attributed to mechanical technology, alloy type and the ewer concerned from ancient period. The ewer was made by cold-working and the spout was joined mechanically. The studied ewer was investigated with a variety of analytical methods. The results show that the structure and the composition of the corrosion are influenced by original composition of copper-arsenic alloy. In general the ewer had very thin metallic thickness, missing parts and corrosion products. The examination under optical, metallographic and SEM conditions allowed us to identify the nature of the alloy, characterized by the presence of cracks or fissures and cavities. EDX analysis indicated that the ewer was made of copper-arsenic alloy. The examination of the cross-sectioned patina revealed its complex structure and allowed the identification of three different and irregular layers. These layers are characterized by different chemical composition with variable content of the alloy elements $(\mathrm{Cu}$ and $\mathrm{AS})$ and elements coming from the soil such as $\mathrm{Cl}$, and $\mathrm{S}$.

The XRD results revealed an interaction between soil constituents and the copper-arsenic alloy. The dangers of corrosion products are attributed to the presence of chlorides

\footnotetext{
${ }^{(35)}$ Tylecote, R. F., "Metallurgy in archaeology prehistory metallurgy in the British Isles". London, Edward Arnold Publishers, 1990

${ }^{(36)}$ Martin Odler, Op. Cit., p. 245.
} 
contact with metal as showed in cross-section. This type of corrosion is known to be very active especially in presence of humidity.

The corrosion of copper with low arsenic contact is observed in outer corrosion layer which is composed of sulfides corrosion products. The migration of arsenic ions to the metal surface resulted in the formation of corrosion products with a higher concentration causes a failed of ewer alloy. To keep this unique copper-arsenic ewer the treatment processes were carried out by mechanical, chemical cleaning and complete the missing parts to support the thin metallic surface in the ewer body; finally the ewer was isolated to protect 


\section{References}

1- Abd El-Rahman, Y., Surour, A.A., El Manawi, A.H.W., Rifai, M, Abd El Motelib, A., and El Dougdoug, A.M., "Ancient mining and smelting activities in the Wadi Abu Gerida area, central eastern desert, Egypt, preliminary results", Archaeometry, 55, 2013, pp.1067-87.

2- Dmitri, K.," The Metallographic Examination of Archaeological Artifacts", Summer Institute In Materials Science And Material Culture, 2003.

3- Frame, L.D., Freestone, I.C., Shu Yan Zhang, and Nicholas, M., "The effects of corrosion and conservation treatments on non-destructive neutron diffraction analysis of archaeological copper alloys: preliminary results", Archaeometry, 55, 2013, pp. 68-80.

4- George Brinton Philips, "The Composition of some Ancient Bronze in the Dawn of the Art of Metallurgy", American Anthropologist, New Series, Vol.24, 1922.

5- Hamilton, D.L., "Methods of conserving archaeological material from underwater sites", Texas University, Texas, 1999, P.83

6- https://www.ancient.eu/Old_Kingdom_of_Egypt/21-3-2018.

7- https://www.google.com.eg/search?q=old+kingdom+longer+Ewer+figur e\&tbm 21-3-2018

8- http://www.reshafim.org.il/ad/egypt/trades/metals.htm 5-1-2018.

9- Ivan De Ryck, Emmanuel Pantos and Annemie Adriaens, "Near Eastern ancient bronze objects from Tell Beydar (NE-Syria): into their Corrosion", Euro-physics News, Vol.38, No.5, 2007.

10- Loï C. Boscher, "Reconstructing the Arsenical Copper Production Process in Early Bronze Age Southwest Asia", PhD, University College London, UCL Qatar, 2016.

11- Lutfia. H. Khalil, "The Composition and Technology Of Copper Artifacts From Jericho And Some Related Sites", PhD, Department of Archaeological Conservation and Materials Science, Faculty of Arts of the University of London, 1980.

12- Maickel Van Bellegem, Philip Fletcher, Paul Craddock,Susan La Niece and Richard Blurton, "The black bronzes of Burma", The British Museum, Vol.1, 2007.

13- Martin Odler, "Old Kingdom Copper Tools and Model Tools", ARCHAEOPRESS Publishing Ltd, Oxford, 2016.

14- Meliksetian K., Schwab R., Kraus S., Pernicka E.and Brauns M., "Chemical, lead isotope and metallographic analysis of extraordinary 
arsenic-rich alloys used for jewellery in Bronze Age Armenia”, Metalla (Bochum) Sonderheft, 4, 2011 1-294.

15- Mohamed Ghoniem, "The Characterization of a Corroded Egyptian Bronze Statue and A Study of the Degradation Phenomena", International Journal of Conservation Science, Volume 2, Issue 2, April-June, 2011, 95108.

16- Mohamed, W., and Darweesh, S., "Ancient Egyptian Black-Patinated Copper Alloys", Archaeometry, 54, 1 (2012) 175-192.

17- Reardon, A.C.," Metallurgy for the Non-Metallurgist", ASM International, 2011.

18- Schorsch, D., "Copper Ewers of Early Dynastic and Old Kingdom Egypt in Antiquity", Philipp Von Zabern, Mainz am Rhein, 1992.

19- Scott, D.A., Metallography and Microstructure of Ancient and Historic Metals, the Getty Conservation Institute, the J. Paul Getty Trust, 1991.

20- Scott, D. A. Copper and Bronze in Art: Corrosion, Colorants, Conservation. Los Angeles, J. P. Getty Museum, 2002.

21- Selwyn, L. Metals and Corrosion: A Handbook for the Conservation Professional. Canada, Canadian Conservation Institute, 2004

22- Selwyn, L., and Binnie, N., "Metal corrosion rates in aqueous treatments for water logged wood- metal composites", Journal of studies in conservation, 38, 1993, pp. 197-180.

23- Srinivasan, S., and Ranganathan, S., "Nonferrous Materials Heritage of Mankind", Trans. Indian Ins. Met., Vol.59, No.6, December 2006, pp.829846.

24- Stephen Michael Vinson," Boats of Egypt before the Old Kingdom", M.A, College of Texas A\&M University, 1987.

25- Subramanian, P.R., and Laughlin, D.E., "The As-Cu (Arsenic-Copper) system", Bulletin of alloy phase Diagram, Vol.9, No. 5, 1988, pp.605-617.

26- Tylecote, R. F. Metallurgy in archaeology prehistory metallurgy in the British Isles. London, Edward Arnold Publishers, 1990

27- Von der Fakultät für Werkstoffwissenschaft und Werkstofftechnologie', "Material properties of copper alloys containing arsenic, antimony, and bismuth The material of Early Bronze Age ingot torques", $\mathrm{PhD}$, Technischen Universität Bergakademie Freiberg, 2003. 


\section{دراسة حالة ابريق من سبيكة النحاس والزرنيخ بالمتحف المصري

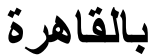

\section{أ.م.د. عبير غريب عبدالله}

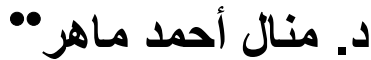

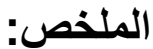

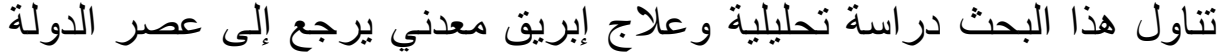

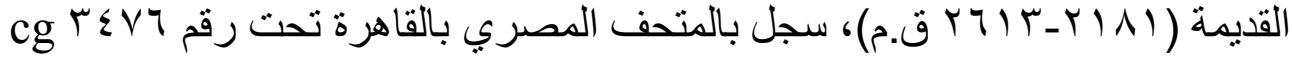

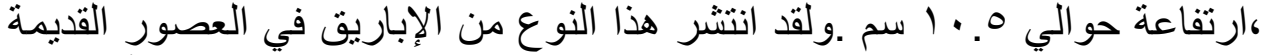

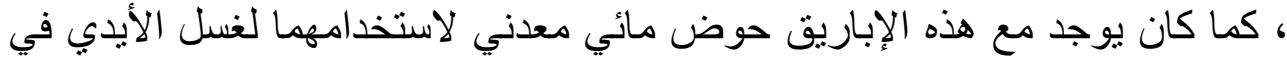

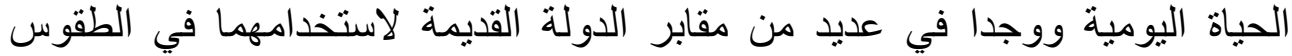

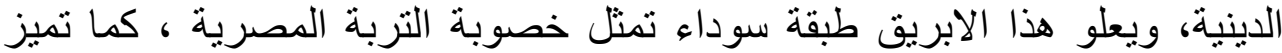

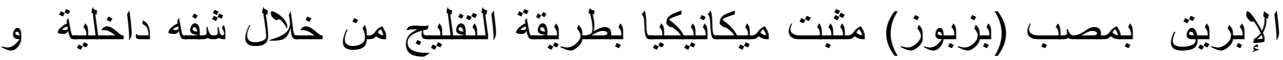

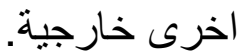

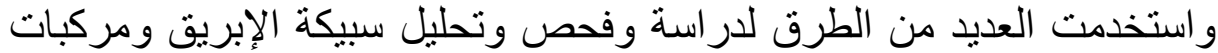

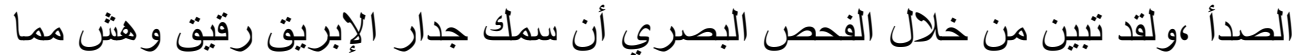

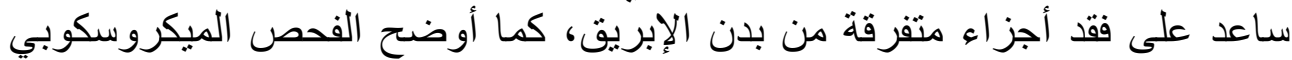

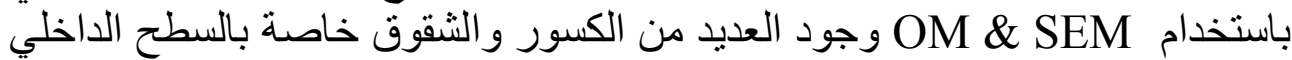

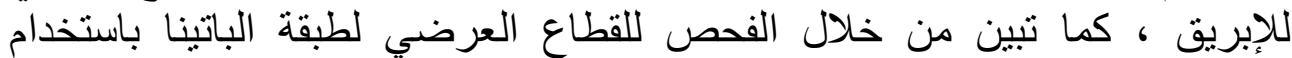

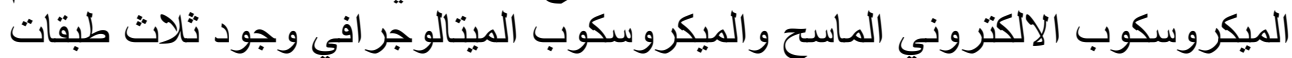

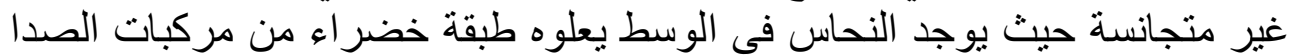

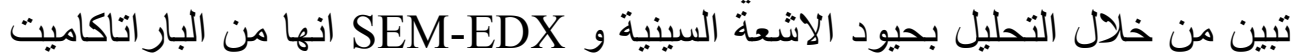

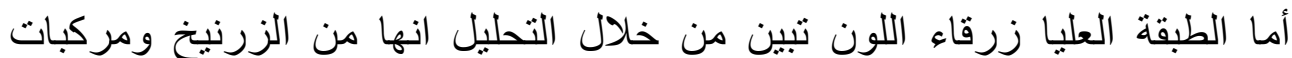

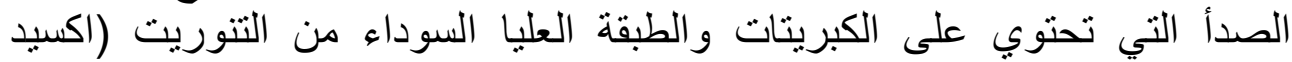

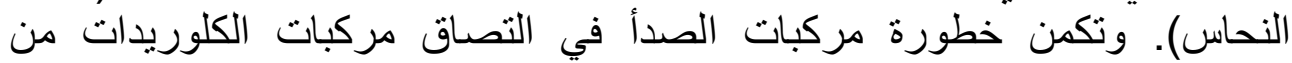

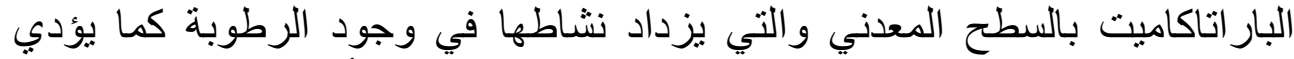

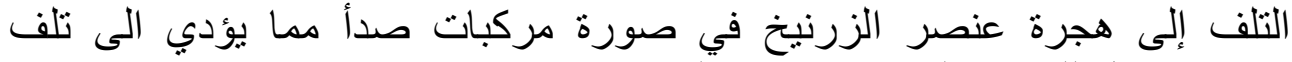
و انهيار كامل للسبيكة المعدنية بمرور الوقت في لتون.

•أستاذ مساعد، قسم ترميم الآثار ، كلية الفنون الجميلة، جامعة المنيا. abeer.ibrahim@mu.edu.eg ••دكتور بمركز تكنولوجيا النانو والفيزياء ، جامعة القاهرة. 


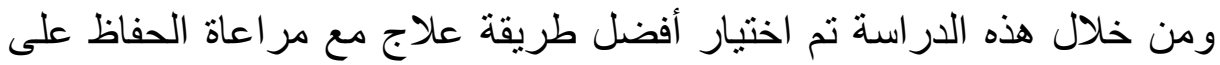

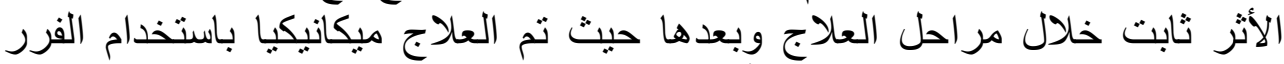

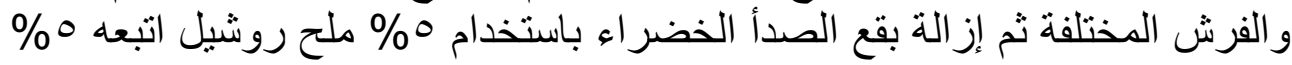
حمض سنريك ذائب في الماء المقطر والثطف الجيد بالماء المقطرثم التجفيف

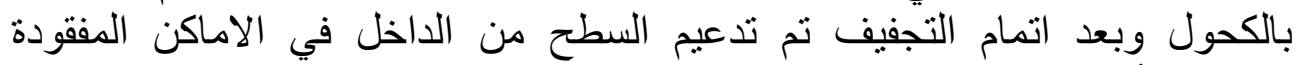

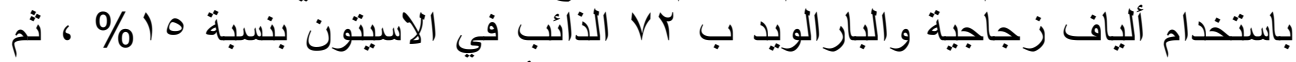

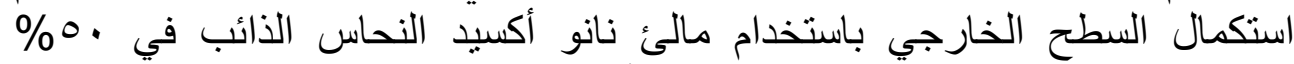

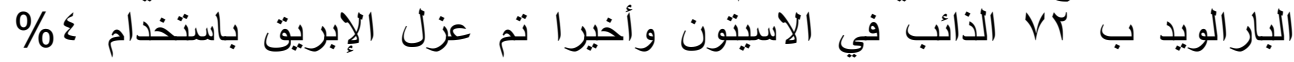

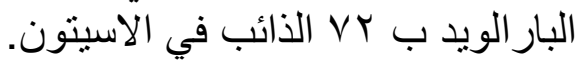

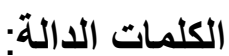

سبائك النحاس والزرنيخ- الإرتباط الميكانيكي - الفحص الميكروسكوبي( الضوئي الالكتروني الماسح- الميتالوجر افي) - التحليل بحيود الاشئي التعة السينية ـ العلاج. 